\title{
Mace Oil
}

National Cancer Institute

\section{Source}

National Cancer Institute. Mace Oil. NCI Thesaurus. Code C107326.

The essential oil of the nutmeg (Myristica fragrans). Mace oil is used as a flavoring and in pharmaceuticals for its analgesic, antispasmodic, laxative, and stimulant activities. 